\title{
Characterization of the active site of monkey sperm hyaluronidase
}

\author{
A. I. Yudin ${ }^{1}$, M-W. Li ${ }^{1}$, K. R. Robertson ${ }^{1}$, G. N. Cherr ${ }^{2}$ and \\ J. W. Overstreet ${ }^{1 *}$ \\ ${ }^{1}$ Division of Reproductive Biology, Department of Obstetrics and Gynecology, and \\ ${ }^{2}$ Bodega Marine Laboratory, University of California, Davis, CA, USA
}

The mammalian sperm hyaluronidase, $\mathrm{PH}-20$, is active in macaque spermatozoa at neutral and acid $\mathrm{pH}$. Antibodies were produced to synthesized peptides representing regions of $\mathrm{PH}-20$ that may be involved in hyaluronidase activity and designated peptide 1 (amino acid sequence 142-172) and peptide 3 (amino acid sequence 277-297). Western blotting of proteins extracted from the surface of acrosome-intact spermatozoa showed that the two peptide-specific, affinity-purified IgGs label a $64 \mathrm{kDa}$ band corresponding to the PH-20 molecule. Western blots of acrosome-reacted spermatozoa showed that, under reducing conditions, the two anti-peptide IgGs label the $44 \mathrm{kDa}$ band only, which represents the $\mathrm{N}$-terminal fragment of $\mathrm{PH}-20$. Anti-peptide $3 \mathrm{IgG}$ also labels the $53 \mathrm{kDa}$ form of $\mathrm{PH}-20$ in extracts of acrosome-reacted spermatozoa. Peptide-specific, affinity-purified Fab frag- ments from both IgGs were shown by fluorescence microscopy and transmission electron microscopy to label the sperm plasma membrane, fused acrosomal vesicles, acrosomal matrix and inner acrosomal membrane. Fab fragments of anti-peptide $1 \mathrm{IgG}$, but not anti-peptide $3 \mathrm{IgG}$, inhibited hyaluronidase activity of $\mathrm{PH}-20$ from the sperm surface and from extracts of acrosome-reacted spermatozoa at pH 7.0. Fab fragments of both anti-peptide IgGs inhibited sperm hyaluronidase activity at pH 5.0. It is concluded that the region of $\mathrm{PH}-20$ encompassed by the amino acid sequence $142-172$ is essential for hyaluronidase activity at neutral $\mathrm{pH}$, whereas the region of amino acid sequence 277-297 may be more important at a lower $\mathrm{pH}$. It is likely that these two regions are the acid/base catalyst site and the nucleophilic site, respectively, of $\mathrm{PH}-20$ hyaluronidases.

\section{Introduction}

Glycosidases are a diverse group of enzymes that catalyse the hydrolysis of glycosidic bonds (Henrissat and Bairoch, 1993; Davies and Henrissat, 1995; Mark et al., 1998). The hyaluronidases comprise a family of the glycosidases that has been exceedingly difficult to purify and characterize, because of their low concentration and structural instability (Kreil, 1995). The substrate for the hyaluronidases is hyaluronic acid, a ubiquitous, structurally simple molecule that is involved in numerous physiological and pathological processes (Toole, 1997). An overabundance of hyaluronic acid and increase of hyaluronidase activity are wellrecognized features of tumorigenesis and are the subject of current investigation (West and Kumar, 1989; Csoka et al., 1997; Lokeshwar et al., 1999; Madan et al., 1999).

A number of mammalian hyaluronidases have been discovered, including ubiquitous and tissue-specific forms (Csoka et al., 1999). The most widely recognized tissuespecific source of hyaluronidase is the mammalian testis, identified originally as a source of 'spreading factor' (Chain

*Address for correspondence: Institute of Toxicology and Environmental Health, One Shields Avenue, University of California, Davis, CA 95616, USA

Email: jwoverstreet@ucdavis.edu and Duthie, 1939). Hyaluronidase was identified subsequently with spermatozoa and was implicated in the mechanism of sperm-oocyte interaction (Austin, 1960). $\mathrm{PH}-20$ is a glycosyl-phosphatidylinositol (GPI)-anchored sperm surface glycoprotein found on all the mammalian spermatozoa that have been examined (Myles and Primakoff, 1997). The cloning of bee venom hyaluronidase uncovered a marked cDNA sequence homology with $\mathrm{PH}-20$ (Gmachl and Kreil, 1993; Lin et al., 1994) and led to the recognition that $\mathrm{PH}-20$ was likely to have hyaluronidase activity. There is now strong evidence that $\mathrm{PH}-20$ is the only hyaluronidase in spermatozoa of guinea-pigs (Hunnicutt et al., 1996), rats (Hou et al., 1996), macaques (Cherr et al., 1996; Li et al., 1997) and humans (Sabeur et al., 1997).

Although the mammalian hyaluronidases are derived from different genes, it is reasonable that these enzymes share certain structural and biological characteristics with one another and with other glycosidases. The glycosidases characteristically have two acidic amino acids that function as either the acid/base catalyst or the nucleophilic site (Braithwaite et al., 1997; Zverlov et al., 1998). Arming et al. (1997) used in vitro mutagenesis of $\mathrm{PH}-20$ to show that two acidic amino acids are critical for enzyme activity. In the present study, these putative catalytic sites of $\mathrm{PH}-20$ were investigated by synthesizing peptides to the corresponding regions and producing polyclonal antibodies to the synthesized peptides. 


\section{Materials and Methods}

\section{Reagents}

The chemicals used for media preparation and experimental techniques were all purchased from Sigma Chemical Company (St Louis, MO), unless specified otherwise.

\section{Antibodies}

Recombinant cynomolgus macaque sperm $\mathrm{PH}-20$ (recombinant $\mathrm{PH}-20$ ) was generated and purified as reported by Lin et al. (1993) and was a gift from P. Primakoff (Department of Cell Biology and Human Anatomy, University of California, Davis) and D. Myles (Department of Molecular and Cellular Biology, University of California, Davis). Two New Zealand white rabbits were given a series of s.c. injections of $50 \mu \mathrm{g}$ recombinant $\mathrm{PH}-20$. The first injection included complete Freund's adjuvant, whereas the subsequent three injections included incomplete Freund's adjuvant. Both rabbits were exsanguinated after the fourth injection, which was approximately 2 months after the series was initiated. The serum was inactivated at $56^{\circ} \mathrm{C}$ for $1 \mathrm{~h}$ in a waterbath.

IgG was purified using ImmunoPure ${ }^{\circledR} \lg$ (protein A) purification kit (Pierce, Rockford, IL). In brief, the inactivated serum was diluted with ImmunoPure ${ }^{\circledR}$ binding buffer and applied to a pre-equilibrated protein A column. After washing with the binding buffer, the bound IgG was eluted with ImmunoPure ${ }^{\circledR} \lg G$ elution buffer. After concentration with a Centricon 50 ultrafiltration tube (Millipore, Bedford, $M A)$, the eluted IgG in elution buffer was applied to D-Salt ${ }^{\mathrm{TM}}$ excellulose desalting column (Pierce) and equilibrated with Dulbecco's PBS (DPBS) to remove salts and change the buffer to DPBS. Fab fragments were prepared from purified whole $\lg G$ as described by Cherr et al. (1996).

Synthetic peptides were produced and anti-peptide antibodies were developed by Zymed Laboratories (South San Francisco, CA). Two potential catalytic sites for $\mathrm{PH}-20$ were identified. The region designated as peptide 1 encompasses the amino acid sequence 142-172 (AVIDWEEWRPTWARNWKPKDVYKNRSIELV). A second region with characteristics of an enzyme catalytic site was designated peptide 3 and includes the amino acid sequence 277-297 (YVRNRVREAIRVSKIPDAKN). The amino acid sequence for each peptide was evaluated for probable antigenicity and the likelihood that the peptide region is located on the protein surface. The constructed peptides were coupled to the carrier protein, keyhole limpet haemocyanin. Antibody titres were evaluated by Zymed Laboratories and the rabbits were exsanguinated approximately 2 months after the initial injection. Zymed furnished the whole rabbit serum, whole IgG, specific antipeptide IgGs and Fab fragments of the anti-peptide IgGs.

\section{Sperm collection}

All animals were housed at the California Regional Primate Research Center in compliance with the Federal
Animal Welfare Act and the National Institute of Health Guidelines for Care and Use of Laboratory Animals. Semen was collected from male cynomolgus macaques by electroejaculation (Sarason et al., 1991). Each ejaculate was collected into a $15 \mathrm{ml}$ conical tube and covered immediately with $5 \mathrm{ml}$ Hepes-buffered Biggers, Whitten and Whittingham (BWW) medium (Irvine Scientific, Santa Ana, CA). Samples were allowed to stand at room temperature for $30 \mathrm{~min}$ before the upper $4 \mathrm{ml}$ was removed and centrifuged for $5 \mathrm{~min}$ at $300 \mathrm{~g}$.

\section{Preparation of $\mathrm{PH}-2 \mathrm{O}$}

After centrifugation, sperm pellets were resuspended in $5 \mathrm{ml}$ DPBS (Life Technologies, Rockville, MD) and recentrifuged for $5 \mathrm{~min}$ at $300 \mathrm{~g}$. The resulting pellet was layered onto $4 \mathrm{ml}$ of a suspension of $40 \%$ (v/v) Percoll in DPBS and centrifuged at $300 \mathrm{~g}$ for $15 \mathrm{~min}$. The spermatozoa were washed two more times by centrifugation and resuspension in $10 \mathrm{ml}$ DPBS before treatment as described below.

Washed acrosome-intact spermatozoa were resuspended at a concentration of $4.0 \times 10^{7}$ spermatozoa $\mathrm{ml}^{-1}$ in DPBS containing $2 \mathrm{U}$ phospholipase C-phosphatidylinositol $\mathrm{ml}^{-1}$ to recover plasma membrane $\mathrm{PH}-20$. Protease inhibitors (20 mmol EDTA l-1, $1 \mathrm{mmol} p$-hydroxymercurobenzenzoate $\mathrm{I}^{-1}, 5 \mathrm{mmol} \mathrm{N}$-ethymaleimide $\mathrm{I}^{-1}$ and $1 \mathrm{mmol}$ benzamidine $\left.\right|^{-1}$ ) were added and the sample was rolled at a $30^{\circ}$ angle from side to side at 28 rotations $\min ^{-1}$ at $37^{\circ} \mathrm{C}$ for $2 \mathrm{~h}$ (Li et al., 1997). After the $2 \mathrm{~h}$ incubation, the sperm sample was microcentrifuged at $2000 \mathrm{~g}$ for $10 \mathrm{~min}$ and then passed through a $0.22 \mu \mathrm{m}$ filter (Fisher Scientific) and stored at $-80^{\circ} \mathrm{C}$ until needed. Before use, the phospholipase C-phosphatidylinositol-released protein extracts were pooled followed by ultracentrifugation at $100000 \mathrm{~g}$ at $4^{\circ} \mathrm{C}$ for $1 \mathrm{~h}$.

Washed spermatozoa were incubated for $2 \mathrm{~h}$ at $37^{\circ} \mathrm{C}$ in BWW medium containing $3 \mathrm{mg} \mathrm{BSA} \mathrm{ml}^{-1}$ to obtain endoproteolysed $\mathrm{PH}-20$ from acrosome-reacted spermatozoa. After incubation, spermatozoa were activated by addition of

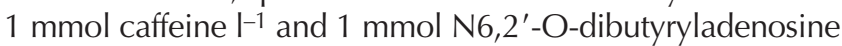
$3^{\prime}: 5^{\prime}$-cyclic monophosphate sodium salt $\mathrm{l}^{-1}$ (dbcAMP). The spermatozoa were incubated for an additional $30 \mathrm{~min}$ and then washed twice with DPBS to remove the BSA. The spermatozoa were resuspended in DPBS at a concentration of $1.0 \times 10^{7}$ spermatozoa $\mathrm{ml}^{-1}$ and were treated with $15 \mu \mathrm{mol} \mathrm{Ca}{ }^{2+}$ ionophore $\mathrm{A} 23187 \mathrm{I}^{-1}$ for $30 \mathrm{~min}$ at $37^{\circ} \mathrm{C}$ to induce acrosome reaction. The spermatozoa were washed and the pellet was resuspended at a concentration of $10^{8}$ spermatozoa $\mathrm{ml}^{-1}$ in DPBS containing protease inhibitors and $30 \mathrm{mmol} n$-ocyl $B$-D-glucopyranoside (OG) $\mathrm{I}^{-1}$. OG extraction continued for $1 \mathrm{~h}$ at $4^{\circ} \mathrm{C}$ with low speed centrifugation at $300 \boldsymbol{g}$ for $10 \mathrm{~min}$, ultracentrifugation at $100000 \boldsymbol{g}$ for $1 \mathrm{~h}$, followed by $0.22 \mu \mathrm{m}$ filtration. The OGextracted sperm proteins were stored at $-80^{\circ} \mathrm{C}$ until used.

\section{Immunoblotting}

Phospholipase C-phosphatidylinositol-released sperm surface proteins were concentrated to $1 \mathrm{mg} \mathrm{ml}^{-1}$ using 
Centricon 10 ultrafiltration tubes, and then solubilized (0.3 mol Tris $\mathrm{I}^{-1}, 5 \%(\mathrm{w} / \mathrm{v})$ SDS and $50 \%(\mathrm{v} / \mathrm{v})$ glycerol, $\mathrm{pH}$ 6.8) and boiled for $3 \mathrm{~min}$. The OG extract from acrosomereacted spermatozoa was centrifuged at $300 \boldsymbol{g}$ for $10 \mathrm{~min}$ and the supernatant was mixed 1:1 with solubilizing buffer, which included $5 \%(\mathrm{v} / \mathrm{v})$ mercaptoethanol as a reducing agent.

Electrophoresis of the surface proteins of phospholipase C-phosphatidylinositol-treated acrosome-intact spermatozoa and the OG extract of acrosome-reacted spermatozoa was carried out using precast $10 \%(\mathrm{v} / \mathrm{v})$ Tris-glycine gels (Fisher Scientific). Approximately $5 \mu \mathrm{g}$ sperm protein was loaded onto each well. After electrophoresis, the gel was either silver stained (Bio-Rad, Hercules, CA) or electroblotted to nitrocellulose membranes and blocked for at least $2 \mathrm{~h}$ in TBS (50 mmol Tris- $\mathrm{HCl} \mathrm{I-1,} \mathrm{pH} \mathrm{7.5,} 0.3 \mathrm{~mol} \mathrm{NaCl} \mathrm{l}^{-1}$ ) containing 5\% (w/v) nonfat dry milk and $0.1 \%(\mathrm{w} / \mathrm{v}) \mathrm{NaN}_{3}$. Blots were washed in TTBS $\left(10 \mathrm{mmol}\right.$ Tris- $\mathrm{HCl}{ }^{-1}, \mathrm{pH} 7.5$, containing $150 \mathrm{mmol} \mathrm{NaCl} \mathrm{I}^{-1}$ and $0.1 \%(\mathrm{v} / \mathrm{v})$ Tween 20) and incubated with each IgG for $2 \mathrm{~h}$ in TBS with $3 \%(\mathrm{w} / \mathrm{v})$ BSA and $0.1 \%(\mathrm{w} / \mathrm{v}) \mathrm{NaN}_{3}$. The blots were washed thoroughly in TTBS and transferred subsequently to goat anti-rabbit IgG-alkaline phosphatase (Bio-Rad) at a concentration of $1: 3000$ in TBS with $3 \%(\mathrm{w} / \mathrm{v})$ BSA and $0.1 \%(\mathrm{w} / \mathrm{v}) \mathrm{NaN}_{3}$. After washing in TTBS, immune complexes were detected using precipitating alkaline phosphatase substrate (one-step NBT-BCIP; Pierce).

\section{Immunolocalization}

Washed ejaculated spermatozoa were resuspended in $1 \mathrm{ml}$ BWW-BSA $\left(3 \mathrm{mg} \mathrm{ml}^{-1}\right)$ buffered with sodium bicarbonate $\left(3 \mathrm{mg} \mathrm{ml}^{-1}\right)$. Each $1 \mathrm{ml}$ of sperm preparation was layered onto a $3 \mathrm{ml}$ column of $80 \%(\mathrm{v} / \mathrm{v})$ Percoll in BWW-BSA (Tollner et al., 2000) and centrifuged at $300 \mathrm{~g}$ for $15 \mathrm{~min}$. Spermatozoa were washed twice by dilution in BWW-BSA (30 mg ml-1) and centrifugation at $300 \mathrm{~g}$ for $10 \mathrm{~min}$, were incubated overnight at $25^{\circ} \mathrm{C}, 5 \% \mathrm{CO}_{2}$, and then placed at $37^{\circ} \mathrm{C}, 5 \% \mathrm{CO}_{2}$ for $2 \mathrm{~h}$ before immunolocalization studies were performed.

Acrosome-intact spermatozoa were incubated for $30 \mathrm{~min}$ with $10 \mu \mathrm{g} \mathrm{ml}^{-1}$ of affinity purified Fab fragments of each anti-peptide IgG. The spermatozoa were centrifuged at $300 \mathrm{~g}$ for $10 \mathrm{~min}$ and resuspended in $0.8 \%(\mathrm{w} / \mathrm{v})$ paraformaldehyde in DPBS for $15 \mathrm{~min}$. Fixed spermatozoa were washed three times in blocking solution $(1 \%(\mathrm{w} / \mathrm{v}) \mathrm{BSA}$ in DPBS with $\left.0.2 \%(\mathrm{w} / \mathrm{v}) \quad \mathrm{NaN}_{3}\right)$, and were incubated subsequently for $1 \mathrm{~h}$ in a 1:10 (v/v) solution of goat antirabbit Fab IgG conjugated with FITC (E-Y Laboratories, Hercules, CA) in blocking solution. Labelled spermatozoa were washed thoroughly and suspended in a 1:1 solution of glycerol and $1 \%(\mathrm{w} / \mathrm{v})$ paraformaldehyde in DPBS. Acrosomereacted spermatozoa were obtained by treatment with ionophore A23187 as described earlier in the presence of Fab fragments of each anti-peptide IgG. The procedures for immunolabelling acrosome-reacted spermatozoa were the same as described earlier.
Photomicrographs were taken of representative spermatozoa using an Olympus BX-60 microscope fitted with a fluorescein filter with excitation at wavelength $480 / 30 \mathrm{~nm}$ and emission at wavelength 535/40 nm. Images were captured and processed using a Zeiss Axiocam digital camera and Axiovision software (Carl Zeiss Vision GmbH, Germany).

For fine structural observations, acrosome-intact and acrosome-reacted spermatozoa were treated as described earlier except that the secondary antibody was goat antirabbit Fab conjugated with either $15 \mathrm{~nm}$ or $10 \mathrm{~nm}$ gold particles (E-Y Laboratories). After incubation for $1 \mathrm{~h}$ in the secondary antibody, the spermatozoa were fixed again in $2.5 \%(\mathrm{w} / \mathrm{v})$ glutaraldehyde in $0.2 \mathrm{~mol}$ cacodylate buffer $\mathrm{I}^{-1}$ $(\mathrm{pH}$ 7.4). Spermatozoa were fixed for at least $1 \mathrm{~h}$, washed twice in 0.2 mol cacodylate buffer $\mathrm{I}^{-1}$ and then post-fixed in $1 \%(\mathrm{w} / \mathrm{v})$ osmium tetroxide (Ted Pella Inc., Redding, CA). After exposure to osmium for $2 \mathrm{~h}$, the spermatozoa were dehydrated through a graded alcohol series and embedded in epoxy resin. Sections were cut on a diamond knife, stained with lead citrate and viewed with a Phillips 400 transmission electron microscope.

\section{Hyaluronic acid substrate gel assay}

The hyaluronic acid substrate gel assay was performed using the method of Guntenhoner et al. (1992), as modified by Cherr et al. (1996). Concentrated phospholipase C-released sperm surface proteins or the OG extracts of acrosomereacted whole spermatozoa were dissolved in SDS solubilization buffer without boiling. The samples were subjected to electrophoresis on $7.5 \%(\mathrm{w} / \mathrm{v})$ SDS-polyacrylamide gels containing hyaluronic acid (Cherr et al., 1996). After electrophoresis, gels were incubated for $2 \mathrm{~h}$ at room temperature in $50 \mathrm{mmol}$ sodium acetate buffer $\mathrm{I}^{-1}$ (at either $\mathrm{pH} 7.0,5.0$ or 4.0) containing $150 \mathrm{mmol} \mathrm{NaCl} \mathrm{I}^{-1}$ and $3 \%(\mathrm{v} / \mathrm{v})$ Triton X-100 to remove SDS and restore in situ hyaluronidase activity. The gels were then incubated for $15 \mathrm{~h}$ at $37^{\circ} \mathrm{C}$ in $50 \mathrm{mmol}$ sodium acetate buffer $\mathrm{I}^{-1}$ (at either $\mathrm{pH} 7.0,5.0$ or 4.0) containing $150 \mathrm{mmol} \mathrm{NaCl} \mathrm{I}^{-1}$. Gels were subsequently stained with $0.5 \%(\mathrm{w} / \mathrm{v})$ Alcian blue in 3\% (v/v) acetic acid for $2 \mathrm{~h}$, destained with $7 \%(\mathrm{v} / \mathrm{v})$ acetic acid, and then counterstained with Coomassie blue (R250) for photography. Prestained protein standards (SeeBlue; Invitrogen Corp, Carlsbad, CA) were used to determine molecular masses.

\section{Hyaluronidase activity inhibition assay}

The assay for hyaluronidase activity was a modification of the method established by Frost and Stern (1997). In brief, after immobilization of biotinylated hyaluronic acid onto 96-well COVALINK-NH microtitre plates (Nunc, Placerville, $\mathrm{NJ}$ ), the plates were equilibrated with extraction buffer (50 mmol Tris- $\mathrm{HCl} \mathrm{I}^{-1}, \mathrm{pH} 7.0$, containing $0.15 \mathrm{~mol} \mathrm{NaCl} \mathrm{I}^{-1}$ and $1 \%(\mathrm{v} / \mathrm{v})$ Triton $\mathrm{X}-100)$. Each well was then filled with $100 \mu \mathrm{l}$ ice-cold ultracentrifuged phospholipase C-phosphatidylinositol-released surface proteins or OGextracted proteins $\left(10^{6}-10^{7}\right.$ spermatozoa $\left.\mathrm{ml}^{-1}\right)$ and incubated for $30-40 \mathrm{~min}$ at $37^{\circ} \mathrm{C}$. Enzyme reaction was 
terminated by the addition of $200 \mu \mathrm{l}$ of $6 \mathrm{~mol}$ guanidine- $\mathrm{HCl} \mathrm{^{-1 }}$ per well followed by three washes of $300 \mu \mathrm{l}$ per well of PBS containing $2 \mathrm{~mol} \mathrm{NaCl} \mathrm{l}^{-1}, 50 \mathrm{mmol}$ $\mathrm{MgSO}_{4} \mathrm{I}^{-1}$ and $0.05 \%$ (v/v) Tween 20. An ABC kit (Vector Laboratories, Burlingame, CA) was prepared in $10 \mathrm{ml}$ PBS containing $0.1 \%(\mathrm{v} / \mathrm{v})$ Tween 20 , incubated for $30 \mathrm{~min}$ and then $100 \mu \mathrm{l}$ was added to each well. After $30 \mathrm{~min}$ of incubation, followed by five washes with PBS washing buffer, $100 \mu \mathrm{l}$ of $1 \mathrm{mg}$ o-phenylenediamine $\mathrm{ml}^{-1}$ in citrate$\mathrm{Na}_{2} \mathrm{HPO}_{4}$ buffer ( $\mathrm{pH}$ 5.3) was added to each well. Plates were incubated for 10-15 min in the dark and read at $490 \mathrm{~nm}$ in an Emax precision microplate reader (Molecular Devices, Sunnyvale, CA). Hyaluronidase activity was determined relative to a four-parameter standard curve established using serial dilutions of a commercial bovine testicular hyaluronidase preparation (Wydase; Wyeth Laboratories Inc., Philadelphia, PA) at pH 7.0 in 50 mmol Tris- $\mathrm{HCl} \mathrm{I}^{-1}$ containing $150 \mathrm{mmol} \mathrm{NaCl} \mathrm{I}^{-1}$. Enzyme activity was measured in turbidity reducing units $\mathrm{ml}^{-1}$ and standard curves were determined in triplicate for each assay. Fab fragments of each anti-peptide IgG were analysed for ability to inhibit the enzyme activity of phospholipase C-phosphatidylinositol-released $\mathrm{PH}-20$ from the plasma membrane and of $\mathrm{PH}-20$ extracted from whole spermatozoa to examine the effects of specific anti-peptide antibodies. Fab fragments $\left(20 \mu \mathrm{g} \mathrm{ml}^{-1}\right)$ were combined 1:1 with the phospholipase C-phosphatidylinositol-released proteins or the OG extraction solution containing protease inhibitors, and incubated overnight at $4^{\circ} \mathrm{C}$ before addition to the microplate wells. Control assays containing the sperm extract and pre-immune $\operatorname{lgG}$ were carried out simultaneously.

The assay for hyaluronidase activity at $\mathrm{pH} 5.0(50 \mathrm{mmol}$ sodium acetate buffer $\mathrm{I}^{-1}$ containing $150 \mathrm{mmol} \mathrm{NaCl} \mathrm{I}^{-1}$ ) was a modification of the method established by Tung et al. (1994). In brief, the mixture of hyaluronic acid (final $0.8 \mathrm{mg} \mathrm{m}^{-1}$ ) and agarose (final $0.8 \% \mathrm{w} / \mathrm{v}$ ) in distilled water was dispensed in $100 \mu \mathrm{l}$ aliquots into each well of a 96-well microplate with a multichannel pipette and the microplate was put in the refrigerator to allow the gel to set. Each well was filled with $100 \mu \mathrm{l}$ of a preincubated mixture of sample and Fab fragments or sample containing only protease inhibitors at $\mathrm{pH}$ 5.0. After $2 \mathrm{~h}$ pre-incubation at room temperature and $5 \mathrm{~h}$ incubation at $37^{\circ} \mathrm{C}$, the enzyme samples were removed and each well was washed three times with $150 \mu \mathrm{l}$ DPBS and filled with $100 \mu \mathrm{l} 10 \%$ (w/v) aqueous cytelpyridinium chloride. After $1 \mathrm{~h}$ at room temperature, the absorbance at $570 \mathrm{~nm}$ was measured by a microplate reader (MR600; Dynatech Laboratories Inc., Alexandria, VA).

\section{Results}

Immunoblotting of sperm proteins with antirecombinant $\mathrm{PH}-20 \lg G$ and anti-peptide $\lg G$ s

After electrophoresis of the surface proteins released by phospholipase C-phosphatidylinositol treatment of acrosome-intact spermatozoa, silver staining of the gel

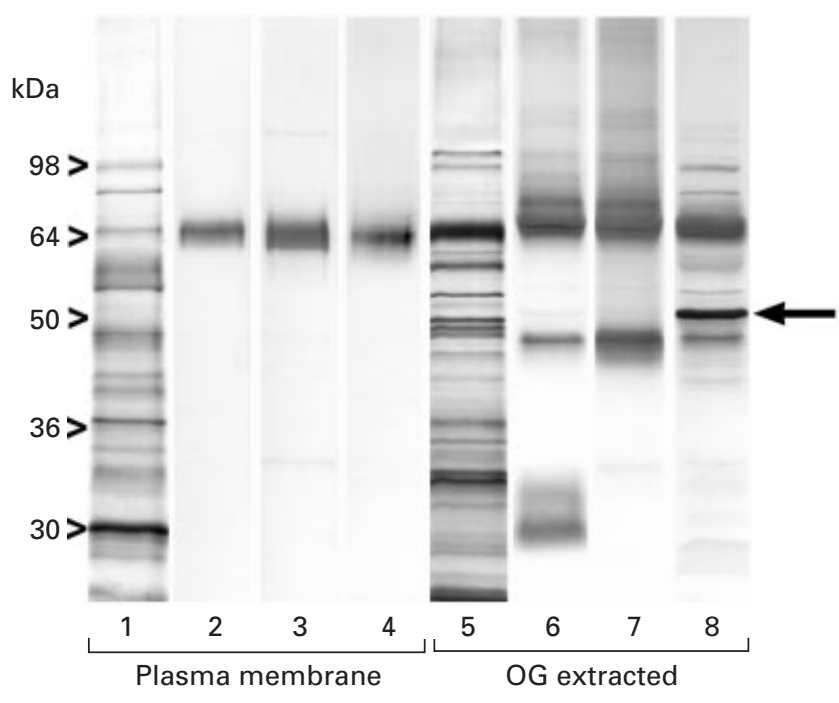

Fig. 1. Western blot analysis of phospholipase C-phosphatidylinositol-released macaque sperm surface proteins (plasma membrane) and $n$-ocyl $B$-D-glucopyranoside (OG)-extracted, whole acrosome-reacted spermatozoa. Lanes 1-4 show analysis of the phospholipase C-phosphatidylinositol-released sperm proteins. Lane 1 is a silver stained gel of the phospholipase C-phosphatidylinositol-released surface proteins. Lane 2 was probed with IgG from a polyclonal antibody to the recombinant $\mathrm{PH}-20(\mathrm{r}-\mathrm{PH}-20)$ protein. Lanes 3 and 4 were probed with specific IgGs to the synthesized peptide 1 and peptide 3, respectively. A single $64 \mathrm{kDa}$ band is recognized by all three antibodies. Lanes 5-8 show analysis of OG-extracted whole acrosome-reacted spermatozoa. The sperm proteins were reduced during solubilization. Lane 5 is a silver stained gel of the proteins that were transferred to nitrocellulose membranes in lanes 6-8. Lane 6 was probed with anti-r-PH-20 lgG, whereas lanes 7 and 8 were probed with anti-peptide $1 \mathrm{lgG}$ and antipeptide $3 \mathrm{IgG}$, respectively. After the acrosome reaction, the anti-r$\mathrm{PH}-20 \mathrm{IgG}$ labels $44 \mathrm{kDa}$ and $30 \mathrm{kDa}$ fragments of proteolysed $\mathrm{PH}-20$ (Lane 6). The $53 \mathrm{kDa}$ form of PH-20 is also recognized faintly by the anti-r-PH-20. The anti-peptide IgGs label the $44 \mathrm{kDa}$ fragment clearly, but not the $30 \mathrm{kDa}$ fragment that represents the carboxyl region of $\mathrm{PH}-20$ (lanes 7 and 8 ). Anti-peptide $3 \lg \mathrm{G}$ labels the $53 \mathrm{kDa}$ form of $\mathrm{PH}-20$ (lane 8, arrow). Both of the anti-peptide IgGs also labelled the nonproteolyzed $64 \mathrm{kDa} \mathrm{PH}-20$ protein.

revealed a number of bands (Fig. 1, lane 1). When these proteins were blotted onto nitrocellulose and probed with anti-recombinant $\mathrm{PH}-20 \lg \mathrm{G}$ and the anti-peptide IgGs, a single $64 \mathrm{kDa}$ band was recognized by all three antibodies (Fig. 1, lanes 2-4). Electrophoresis of the OG extract of acrosome-reacted spermatozoa under reducing conditions also revealed many proteins after silver staining (Fig. 1, lane 5). On nitrocellulose membranes, the anti-recombinant $\mathrm{PH}-20$ IgG recognized a $67 \mathrm{kDa}$ band, as well as $44 \mathrm{kDa}$ and $30 \mathrm{kDa}$ bands (Fig.1, lane 6). In contrast, the anti-peptide IgGs recognized the $67 \mathrm{kDa}$ band and the $44 \mathrm{kDa}$ band, but not the $30 \mathrm{kDa}$ band (Fig. 1, lanes 7 and 8). The lower molecular mass forms have been attributed to endoproteolytic cleavage of the $\mathrm{PH}-20$ protein into two fragments which are disulphide linked (Primakoff et al., 1988). The 
higher molecular mass fragment (44 kDa) is the $\mathrm{N}$-terminal fragment. A $53 \mathrm{kDa}$ band was recognized in the extract of acrosome-reacted spermatozoa by the anti-recombinant $\mathrm{PH}-20 \operatorname{lgG}$ and the anti-peptide $3 \operatorname{lgG}$ (Fig. 1, lanes 6 and 8). The anti-peptide $3 \operatorname{lgG}$ had much greater affinity for this component than did the $\lg \mathrm{G}$ to whole recombinant protein, which recognized the band only faintly. The anti-peptide 1 IgG did not label the $53 \mathrm{kDa}$ band (Fig. 1, lane 7). The $53 \mathrm{kDa}$ form of $\mathrm{PH}-20$ is a significant component of the soluble hyaluronidase released from spermatozoa at the time of the acrosome reaction (Li et al., 1997).

\section{Immunolabelling of spermatozoa with anti-peptide IgGs}

Anti-recombinant PH-20 IgG and Fab fragments of this $\lg \mathrm{G}$ are effective in labelling acrosome-intact spermatozoa, regardless of whether spermatozoa were fixed before labelling (Overstreet et al., 1995; Cherr et al., 1996). In the present study, Fab fragments of anti-peptide IgGs were used for immunolocalization because these fragments resulted in more intense labelling of the sperm plasma membrane than did the whole IgGs (data not shown). In using Fab fragments rather than $\lg \mathrm{G}$ for immunolocalization, any aggregation of surface $\mathrm{PH}-20$ that is induced by incubation of spermatozoa with anti-PH-20 IgG was also avoided (Yudin et al., 1998).

Fab fragments from anti-recombinant $\mathrm{PH}-20 \lg \mathrm{G}$ and the anti-peptide $1 \mathrm{IgG}$ both labelled the entire head of acrosome-intact spermatozoa but not the sperm mid-piece or flagellum (Fig. 2a-d). Fab fragments of anti-peptide 3 IgG did not appear to label the posterior head of acrosomeintact spermatozoa and there was very faint labelling of the sperm mid-piece (Fig. 2e,f). When spermatozoa were induced to undergo the acrosome reaction in the presence of the Fab fragments from all three IgGs, the label was located over the acrosomal cap in the region of the acrosomal shroud (Fig. 3a-f). All acrosome-intact and acrosomereacted spermatozoa appeared to have the labelling patterns shown (Figs 2 and 3, respectively).

At the ultrastructural level, Fab fragments of the antipeptide IgGs labelled the plasma membrane over the head of the acrosome-intact spermatozoa, and there was no labelling of the sperm mid-piece or flagellum. The results with Fab fragments of anti-peptide 1 IgG demonstrate the pattern of labelling (Fig. 4a), and labelling with Fab fragments of anti-peptide 3 IgG gave similar results (not shown). The labelling pattern of acrosome-reacted spermatozoa is illustrated with Fab fragments of antipeptide 3 IgG (Fig. 4b). Labelling with Fab fragments of antipeptide 1 IgG gave similar results (not shown). When spermatozoa began to undergo the acrosome reaction in the presence of Fab fragments of the anti-peptide IgGs, there was immediate labelling of the externalized acrosomal matrix (Fig. 4b). The entire acrosomal shroud, including the acrosomal vesicles, composed of fused plasma membrane and outer acrosomal membrane, was labelled with immunogold particles (Fig. 4b). Recognition of $\mathrm{PH}-20$ by Fab fragments of the anti-peptide IgGs appeared to be more
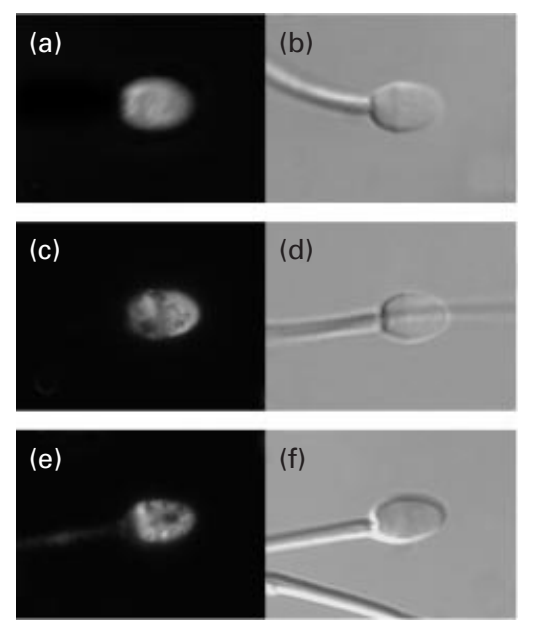

Fig. 2. Macaque spermatozoa exposed to Fab fragments of anti$\mathrm{PH}-20$ IgG before and after the acrosome reaction. (a) Localization of anti-recombinant-PH-20 Fab over the entire head of the acrosome-intact spermatozoa and (b) the corresponding phasecontrast micrograph. Localization of (c) anti-peptide 1 Fab and (e) anti-peptide 3 Fab, with the corresponding phase-contrast micrographs ( $d$ and $f$, respectively).
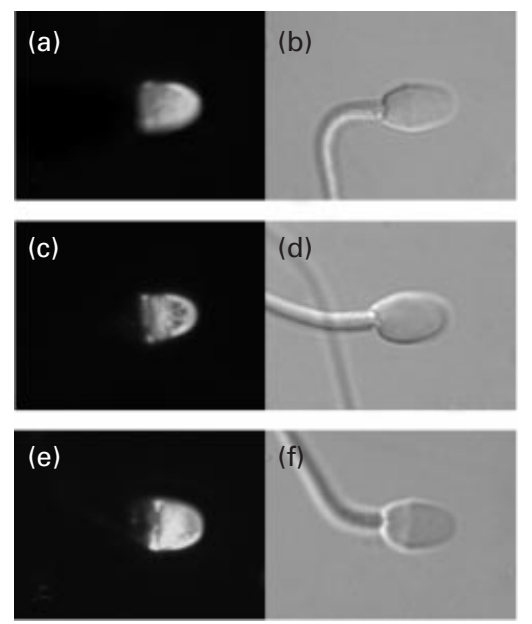

Fig. 3. Acrosome-reacted macaque spermatozoa. Immunolocalization of the Fab fragments of (a) anti-recombinant-PH-20 IgG, (c) anti-peptide $1 \mathrm{IgG}$ and (e) anti-peptide $3 \mathrm{IgG}$ and corresponding phase-contrast micrographs (b, $d$ and $f$, respectively).

intense after the acrosome reaction, and the Fab fragments of both anti-peptide IgGs labelled the inner acrosomal membrane of acrosome-reacted spermatozoa (Fig. 4b).

\section{Hyaluronic acid substrate gel analysis of $\mathrm{PH}-20$}

Hyaluronic acid substrate gel analysis of plasma membrane (phospholipase C-phosphatidylinositol-released) $\mathrm{PH}-20$ revealed a $64 \mathrm{kDa}$ form with highest enzyme activity at pH 7.0 (Fig. 5). A similar analysis of the (OG-extracted) 

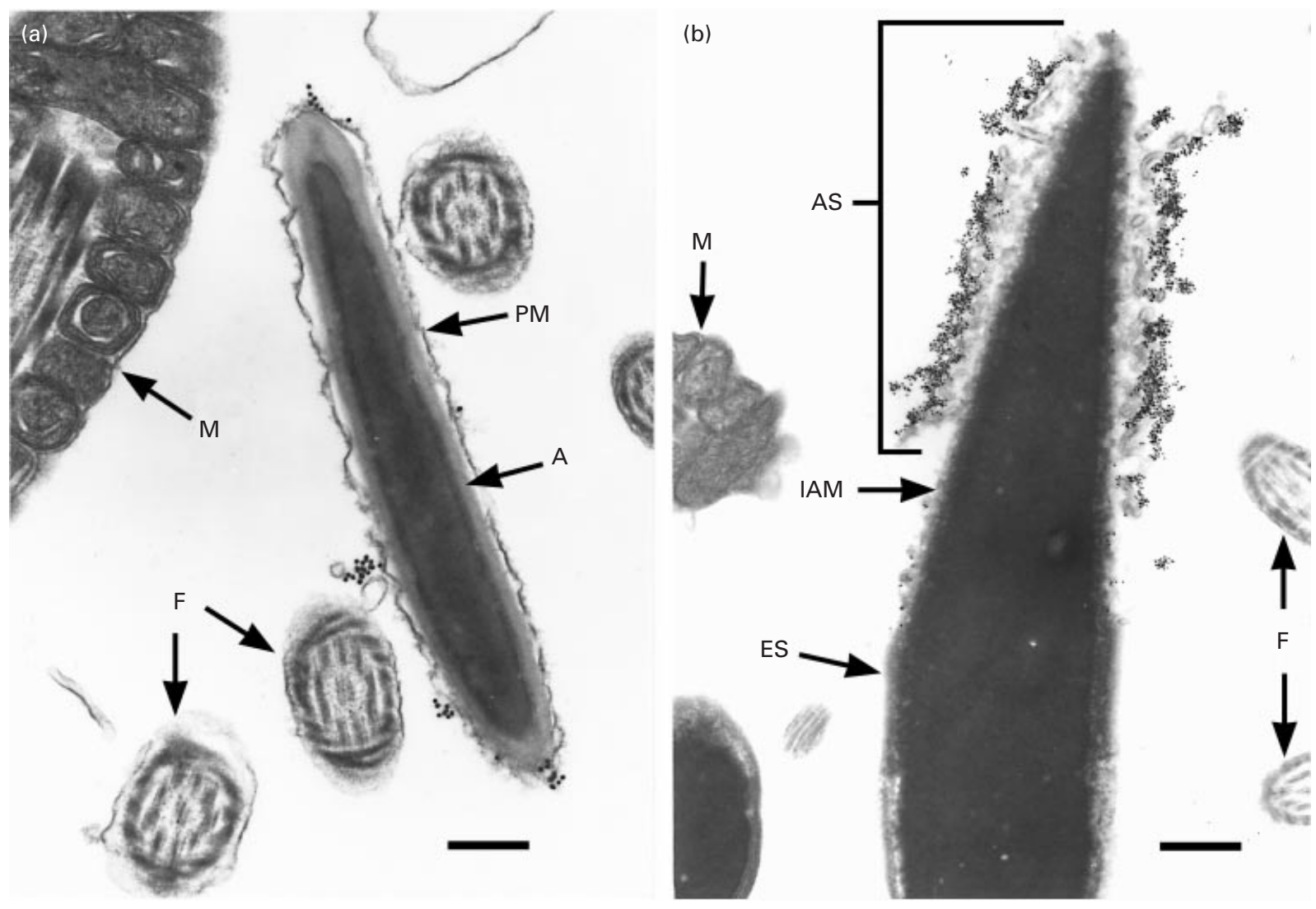

Fig. 4. (a) Immunolocalization of $\mathrm{PH}-20$ on a macaque spermatozoon, using Fab fragments of anti-peptide 1 IgG. The acrosome (A) is intact and the anti-peptide 1 Fab fragments recognize a component of the plasma membrane (PM) over the entire head of the spermatozoon, whereas no gold label is found along the mid-piece $(M)$ or flagellum (F). Scale bar represents $0.3 \mu \mathrm{m}$. (b) Immunolocalization of $\mathrm{PH}-20$ on an acrosome-reacted macaque spermatozoon using Fab fragments of antipeptide $3 \mathrm{lgG}$. The anti-peptide $3 \mathrm{Fab}$ fragments recognize components of the entire acrosomal shroud (AS) including the acrosomal matrix and the inner acrosomal membrane (IAM). There is some label along the equatorial segment (ES) but the antibody does not recognize the plasma membrane over the mid-piece (M) and flagellum (F). Scale bar represents $0.28 \mu \mathrm{m}$.

endoproteolysed $\mathrm{PH}-20$ from acrosome-reacted spermatozoa also revealed the $64 \mathrm{kDa}$ form, as well as a $53 \mathrm{kDa}$ form that was active at $\mathrm{pH} 4.0$ but not at $\mathrm{pH} 5.0$ or $\mathrm{pH} 7.0$ (Fig. 5).

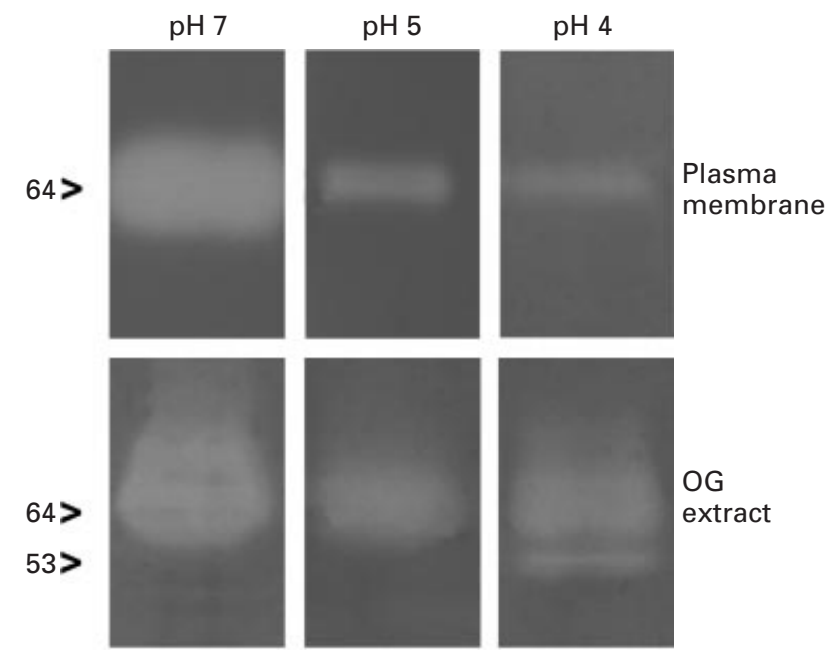

\section{Inhibition of hyaluronidase activity by anti-peptide $\lg G s$}

Of the two anti-peptide IgGs, only Fab fragments of anti-peptide 1 IgG significantly inhibited sperm hyaluronidase activity at $\mathrm{pH} 7.0$, and this inhibition was equally effective on plasma membrane $\mathrm{PH}-20$ (phospholipase C-phosphatidylinositol-released) and $\mathrm{PH}-20$ extracted from whole acrosome-reacted spermatozoa (OG extracted)

Fig. 5. Hyaluronic acid substrate SDS-PAGE $(7.5 \%(\mathrm{w} / \mathrm{v})$ gel) of plasma membrane proteins (phospholipase C-phosphatidylinositol-released) from acrosome-intact spermatozoa and $n$-ocyl $B$-D-glucopyranoside (OG) extracted proteins from whole acrosome-reacted spermatozoa. The experiment was carried out at $\mathrm{pH}$ 4.0, 5.0 and 7.0. The plasma membrane proteins had the highest hyaluronidase activity at $\mathrm{pH} 7.0$ and had only slight activity at $\mathrm{pH}$ 4.0. All of the hyaluronidase activity from the plasma membrane proteins was associated with the $64 \mathrm{kDa}$ form of $\mathrm{PH}-20$. The OG extract had the highest hyaluronidase activity at $\mathrm{pH} 7.0$ but also had significant activity at the lower $\mathrm{pH}$ values. The $53 \mathrm{kDa}$ form of $\mathrm{PH}-20$ had hyaluronidase activity at $\mathrm{pH} 4.0$ only. 
Table 1. Effects of anti-PH-20 antibodies at acid $(\mathrm{pH} \mathrm{5.0)}$ and neutral $(\mathrm{pH} \mathrm{7.0)} \mathrm{pH}$ on the hyaluronidase activity of proteins released from the macaque sperm plasma membrane or of proteins from an extract of acrosome-reacted spermatozoa

\begin{tabular}{|c|c|c|c|c|c|c|c|c|c|}
\hline \multirow[b]{2}{*}{ Extract } & \multirow[b]{2}{*}{ Expt } & \multicolumn{4}{|c|}{ pH 5.0} & \multicolumn{4}{|c|}{$\mathrm{pH} 7.0$} \\
\hline & & $\begin{array}{l}\text { Control } \\
\text { TRU ml }{ }^{-1}\end{array}$ & $\begin{array}{l}\text { Peptide } 1 \text { Fab } \\
\text { (\% Inhibition) }\end{array}$ & $\begin{array}{l}\text { Peptide } 3 \text { Fab } \\
\text { (\% Inhibition) }\end{array}$ & $\begin{array}{l}\text { r-PH-20 Fab } \\
\text { (\% Inhibition) }\end{array}$ & $\begin{array}{l}\text { Control } \\
\text { TRU } \mathrm{ml}^{-1}\end{array}$ & $\begin{array}{l}\text { Peptide } 1 \text { Fab } \\
\text { (\% Inhibition) }\end{array}$ & $\begin{array}{l}\text { Peptide } 3 \text { Fab } \\
\text { (\% Inhibition) }\end{array}$ & $\begin{array}{l}\text { r-PH-20 Fab } \\
\text { (\% Inhibition) }\end{array}$ \\
\hline \multirow[t]{3}{*}{ PLC-PI (surface) } & 1 & 4.4 & $\begin{array}{c}3.8 \\
(14 \%)\end{array}$ & $\begin{array}{c}3.8 \\
(14 \%)\end{array}$ & $\begin{array}{c}3.5 \\
(20 \%)\end{array}$ & 13.7 & $\begin{array}{c}9.3 \\
(32 \%)\end{array}$ & $\begin{array}{l}13.7 \\
(0 \%)\end{array}$ & $\begin{array}{c}5.2 \\
(62 \%)\end{array}$ \\
\hline & 2 & 5.2 & $\begin{array}{c}4.7 \\
(10 \%)\end{array}$ & $\begin{array}{c}4.4 \\
(15 \%)\end{array}$ & $\begin{array}{c}3.7 \\
(29 \%)\end{array}$ & 15.2 & $\begin{array}{l}11.3 \\
(26 \%)\end{array}$ & $\begin{array}{l}14.4 \\
(5 \%)\end{array}$ & $\begin{array}{c}7.3 \\
(52 \%)\end{array}$ \\
\hline & 3 & 4.8 & $\begin{array}{c}4.2 \\
(13 \%)\end{array}$ & $\begin{array}{c}4.0 \\
(17 \%)\end{array}$ & $\begin{array}{c}3.8 \\
(21 \%)\end{array}$ & 10.9 & $\begin{array}{c}7.0 \\
(36 \%)\end{array}$ & $\begin{array}{l}10.3 \\
(6 \%)\end{array}$ & $\begin{array}{c}3.6 \\
(67 \%)\end{array}$ \\
\hline \multirow[t]{3}{*}{ OG } & 1 & 2.9 & $\begin{array}{c}2.2 \\
(24 \%)\end{array}$ & $\begin{array}{c}1.9 \\
(34 \%)\end{array}$ & $\begin{array}{c}1.5 \\
(48 \%)\end{array}$ & 16.4 & $\begin{array}{c}10.7 \\
(35 \%)\end{array}$ & $\begin{array}{l}15.8 \\
(4 \%)\end{array}$ & $\begin{array}{c}6.6 \\
(60 \%)\end{array}$ \\
\hline & 2 & 5.9 & $\begin{array}{c}4.3 \\
(27 \%)\end{array}$ & $\begin{array}{c}3.6 \\
(39 \%)\end{array}$ & $\begin{array}{c}4.3 \\
(27 \%)\end{array}$ & 11.3 & $\begin{array}{c}8.3 \\
(27 \%)\end{array}$ & $\begin{array}{l}10.2 \\
(10 \%)\end{array}$ & $\begin{array}{c}5.9 \\
(48 \%)\end{array}$ \\
\hline & 3 & 8.1 & $\begin{array}{c}5.9 \\
(27 \%)\end{array}$ & $\begin{array}{c}5.6 \\
(31 \%)\end{array}$ & $\begin{array}{c}5.8 \\
(28 \%)\end{array}$ & 19.8 & $\begin{array}{c}14.3 \\
(28 \%)\end{array}$ & $\begin{array}{l}18.5 \\
(7 \%)\end{array}$ & $\begin{array}{c}7.7 \\
(61 \%)\end{array}$ \\
\hline
\end{tabular}

Spermatozoa were treated with phospholipase C-phosphatidylinositol (PLC-PI) to extract sperm surface protein or $n$-ocyl $B$-D-glucopyranoside (OG) to extract proteins from whole acrosome-reacted spermatozoa. Fab fragments of IgG from anti-recombinant-PH-20 (r-PH-20), anti-peptide 1 and anti-peptide 3 antibodies were tested. The assays for hyaluronidase activity were performed at a single concentration $\left(20 \mu \mathrm{g} \mathrm{ml}{ }^{-1}\right)$ of the Fab fragments. Each assay was carried out in triplicate.

TRU: enzyme activity was measured in turbidity reducing units (TRU) $\mathrm{ml}^{-1}$.

$\%$ Inhibition: percentage inhibition of hyaluronidase activity compared with control values.

(Table 1). Fab fragments of anti-recombinant $\mathrm{PH}-20 \lg \mathrm{G}$ were more effective at inhibiting sperm hyaluronidase activity than were the Fab fragments of either anti-peptide IgG (Table 1). At pH 5.0, the two anti-peptide IgGs had similar effectiveness in inhibiting sperm hyaluronidase activity (Table 1). The inhibition appeared to be more effective on $\mathrm{PH}-20$ extracted from acrosome-reacted spermatozoa than on plasma membrane $\mathrm{PH}-20$ (Table 1).

\section{Discussion}

The hyaluronidases appear to have common structural features that are critically important for enzyme activity and are conserved in many species (Csoka et al., 1999). In fact, the $\mathrm{PH}-20$ sperm protein was recognized as a hyaluronidase because of its high degree of amino acid sequence homology with bee venom hyaluronidase (Gmachl and Kreil, 1993).

Arming et al. (1997) constructed a variety of recombinant human $\mathrm{PH}-20$ proteins that were mutated at sites with highly conserved acidic and basic amino acids. All of the mutated proteins were shown to be deficient in hyaluronidase activity at neutral $\mathrm{pH}$. In the present study, peptides 1 and 3 represent two regions of the $\mathrm{PH}-20$ molecule, which include four of the five amino acid mutation sites at which mutation caused a loss of hyaluronidase activity (Arming et al., 1997). Chan et al. (1999) found that the antibodies to $\mathrm{PH}-20$, which caused infertility in female guinea-pigs, had highest titres to a region of the $\mathrm{PH}-20$ molecule that is the same as the peptide 1 region in the present study.
The data obtained in the present study indicate that the peptide 1 region is essential for enzyme activity of $\mathrm{PH}-20$ at neutral $\mathrm{pH}$, and it is likely that it may constitute the acid/base region of the enzyme. The peptide 1 region is characterized by an abundance of aromatic amino acids flanking the catalytic residue, glutamic acid, which is a common feature of other glycosyl hydrolases (Van Roey et al., 1994). Another common feature of these enzymes is the presence of basic amino acids or an organized region of basic amino acids that are used for substrate hyaluronic acid binding or docking (Withers and Aebersold, 1995). Amino acids 150-158 within peptide 1 constitute a $\mathrm{B}(\times 7) \mathrm{B}$ region, which is commonly found in hyaluronic acid binding proteins (Yang et al., 1993).

It has been reported that a natural mutation at amino acid 268 of Hyal 1, the human serum hyaluronidase, resulted in a lack of enzyme activity at acid $\mathrm{pH}$ in the affected individual (Triggs-Raine et al., 1999). In the $\mathrm{PH}-20$ molecule this site corresponds to one of the amino acids mutated by Arming et al. (1997), and falls within the region represented by peptide 3 in the present study. The antibody to the peptide 3 region did not affect the enzyme activity of plasma membrane $\mathrm{PH}-20$ at neutral $\mathrm{pH}$; however, there was evidence of inhibition of sperm hyaluronidase activity by anti-peptide 3 antibody at pH 5.0, particularly when PH-20 was extracted from acrosome-reacted spermatozoa. These data indicate that the peptide 3 region may have a role in acid-active hyaluronidase activity, a finding that is consistent with our previous reports that acid-active hyaluronidase activity is present primarily in spermatozoa that have undergone the acrosome reaction (Cherr et al., 1996). 
Glycosyl hydrolases commonly have two regions that appear to be involved in the catalytic activity of the enzyme (Braithwaite et al., 1997; Zverlov et al., 1998). The sites are centred around either glutamic acid or aspartic acid, and these amino acids act either as an acid catalyst site or as a nucleophilic site (Withers and Aebersold, 1995). It is thought that changes at either site will have a marked effect on the kinetics and the optimum $\mathrm{pH}$ of the enzyme reaction (Braithwaite et al., 1997; Mark et al., 1998). The information available on other enzymes supports the interpretation that the peptide 3 region of $\mathrm{PH}-20$ could modulate the kinetics of hyaluronidase activity over the broad $\mathrm{pH}$ range.

The immunolocalization studies performed in the present study demonstrate that both the peptide 1 and the peptide 3 regions of $\mathrm{PH}-20$ are exposed on the sperm surface, as well as in the soluble forms of the enzyme and in the forms that are bound to the inner acrosomal membrane after the acrosome reaction. The $64 \mathrm{kDa}$ surface $\mathrm{PH}-20$ has its highest hyaluronidase activity at neutral pH ( $\mathrm{Li}$ et al., 1997), and facilitates sperm migration through the cumulus by depolymerizing the cumulus matrix (Meyers et al., 1997). The $\mathrm{PH}-20$ on the inner acrosomal membrane appears to be comprised of both acid active and neutral active enzymes (Li et al., 1997), and it appears to have a function in binding acrosome-reacted spermatozoa to the zona pellucida (Yudin et al., 1999).

Soluble $\mathrm{PH}-20$ is released by macaque spermatozoa during the acrosome reaction (Cherr et al., 1996) and is composed of a $64 \mathrm{kDa}$ form and a $53 \mathrm{kDa}$ form; the latter is thought to be derived from the $64 \mathrm{kDa}$ form on the inner acrosomal membrane (Li et al., 1997). As the $53 \mathrm{kDa}$ form is active only at acid $\mathrm{pH}$, its biological function is not clear (Li et al., 1997). It is possible that the acid active $53 \mathrm{kDa}$ form could function briefly to depolymerize the cumulus matrix in the immediate vicinity of the sperm flagellum as penetration of the zona pellucida begins (Cherr et al., 1996).

In the present study, it was not possible to investigate the effect of anti-peptide antibodies on the acid active $53 \mathrm{kDa}$ hyaluronidase because the $53 \mathrm{kDa}$ form of $\mathrm{PH}-20$ is not active above $\mathrm{pH} 4.0$, and the antibodies used did not bind to $\mathrm{PH}-20$ proteins at $\mathrm{pH} 4.0$ (data not shown). Nevertheless, a functional role for the peptide 3 site on the $53 \mathrm{kDa}$ form of $\mathrm{PH}-20$ is indicated by the binding of the anti-peptide $3 \operatorname{lgG}$ to the $53 \mathrm{kDa}$ form of $\mathrm{PH}-20$ on western blots. Although the antibodies to peptide 1 did not recognize the $53 \mathrm{kDa}$ form of $\mathrm{PH}-20$ on western blots, this result could be due to the potential refolding of the molecule, the relatively smaller amount of this protein or a lower affinity of the anti-peptide 1 antibody for the protein.

The $53 \mathrm{kDa}$ soluble form of $\mathrm{PH}-20$ appears to share some characteristics with the mammalian hyaluronidases, termed Hyal 1, 2 and 3, which are also reported to have a very strict acid $(<4.5) \mathrm{pH}$ requirement (Frost et al., 1997; Strobl et al., 1998; Flannery et al., 1998). Hyal 1, 2 and 3 may promote angiogenesis, and the function of these hyaluronidases in tumour invasion and metastasis is the subject of intense investigation (Csoka et al., 1997; Lepperdinger et al., 1998;
Lokeshwar et al., 1999; Madan et al., 1999; Maingonnat et al., 1999; Victor et al., 1999). Progress made in understanding the actions of hyaluronidase in sperm cells may provide new insights into the mechanisms of malignant changes in other cell types.

In conclusion, the region of $\mathrm{PH}-20$ represented by peptide 1 meets the criteria proposed as characteristic of other glycosidases, and antibodies to this region were shown to reduce the hyaluronidase activity of $\mathrm{PH}-20$ significantly. It is concluded that the region of the $\mathrm{PH}-20$ molecule encompassed by the amino acid sequence 142-172 is essential for neutral-active hyaluronidase activity and it is likely that this is the acid/base catalytic region of the enzyme. The region of the $\mathrm{PH}-20$ molecule designated as peptide 3 may be critical for regulating hyaluronidase activity at lower $\mathrm{pH}$ and could be the nucleophilic site responsible for the enzyme kinetics.

This work was supported by grants from the National Institutes of Health (U54-HD29125, P51-RR00169) and the Andrew W. Mellon Foundation.

\section{References}

Arming S, Strobl B, Wechselberger C and Kreil G (1997) In vitro mutagenesis of $\mathrm{PH}-20$ hyaluronidase from human sperm European Journal of Biochemistry 247 810-814

Austin CR (1960) Capacitation and the release of hyaluronidase from the spermatozoa Journal of Reproduction and Fertility 3 310-311

Braithwaite KL, Barna T, Spurway TD et al. (1997) Evidence that galactanase A from Pseudomonas fluorescens subspecies cellulosa is a retaining family 53 glycosyl hydrolase in which E161 and E270 are the catalytic residues Biochemistry 3615 489-15 500

Chain E and Duthie ES (1939) A mucolytic enzyme in testes extract Nature 144 977-978

Chan CP, Gupta S and Mark GE (1999) Identification of linear surface epitopes on the guinea pig sperm membrane protein PH-20 Life Sciences 64 1989-2000

Cherr GN, Meyers SA, Yudin AI, Vandevoort CA, Myles DG, Primakoff P and Overstreet JW (1996) The $\mathrm{PH}-20$ protein in cynomolgus macaque spermatozoa: identification of two different forms exhibiting hyaluronidase activity Developmental Biology 175 142-153

Csoka AB, Scherer SW and Stern R (1999) Expression analysis of six paralogous human hyaluronidase genes clustered on chromosomes 3 p21 and 7q31 Genomics $60356-361$

Csoka TB, Frost GI, Wong T and Stern R (1997) Purification and microsequencing of hyaluronidase isozymes from human urine FEBS Letters 417 307-310

Davies G and Henrissat B (1995) Structures and mechanisms of glycosyl hydrolases Structure 3 853-859

Flannery CR, Little CB, Hughes CE and Caterson B (1998) Expression and activity of articular cartilage hyaluronidases Biochemical and Biophysical Research Communications 251 824-829

Frost GI and Stern R (1997) A microtiter-based assay for hyaluronidase activity not requiring specialized reagents Analytical Biochemistry 251 263-269

Frost GI, Csoka TB, Wong T and Stern R (1997) Purification, cloning, and expression of human plasma hyaluronidase Biochemical and Biophysical Research Communications 236 10-15

Gmachl M and Kreil G (1993) Bee venom hyaluronidase is homologous to a membrane protein of mammalian sperm Proceedings National Academy of Sciences USA 90 3569-3573

Guntenhoner MW, Pogrel MA and Stern R (1992) A substrate-gel assay for hyaluronidase activity Matrix 12 388-396 
Henrissat B and Bairoch A (1993) New families in the classification of glycosyl hydrolases based on amino acid sequence similarities Biochemical Journal 293 781-788

Hou ST, Ma A, Jones R and Hall L (1996) Molecular cloning and characterization of rat sperm surface antigen 2B1, a glycoprotein implicated in sperm-zona binding Molecular Reproduction and Development 45 193-203

Hunnicutt GR, Mahan K, Lathrop WF, Ramarao CS, Myles DG and Primakoff P (1996) Structural relationship of sperm soluble hyaluronidase to the sperm membrane protein $\mathrm{PH}-20$ Biology of Reproduction 54 1343-1349

Kreil G (1995) Hyaluronidases - a group of neglected enzymes Protein Science 4 1666-1669

Lepperdinger G, Strobl B and Kreil G (1998) HYAL2, a human gene expressed in many cells, encodes a lysosomal hyaluronidase with a novel type of specificity Journal of Biological Chemistry 273 22 466-22 470

Li MW, Cherr GN, Yudin Al and Overstreet JW (1997) Biochemical characterization of the $\mathrm{PH}-20$ protein on the plasma membrane and inner acrosomal membrane of cynomolgus macaque spermatozoa Molecular Reproduction and Development 48 356-366

Lin Y, Kimmel LH, Myles DG and Primakoff P (1993) Molecular cloning of the human and monkey sperm surface protein $\mathrm{PH}-20$ Proceedings National Academy of Sciences USA $9010071-10075$

Lin Y, Mahan K, Lathrop WF, Myles DG and Primakoff P (1994) A hyaluronidase activity of the sperm plasma membrane protein $\mathrm{PH}-20$ enables sperm to penetrate the cumulus cell layer surrounding the egg Journal of Cell Biology 125 1157-1163

Lokeshwar VB, Young MJ, Goudarzi G, lida N, Yudin AI, Cherr GN and Selzer MG (1999) Identification of bladder tumor-derived hyaluronidase: its similarity to HYAL1 Cancer Research 59 4464-4470

Madan AK, Yu K, Dhurandhar N, Cullinane C, Pang Y and Beech DJ (1999) Association of hyaluronidase and breast adenocarcinoma invasiveness Oncology Reports 6 607-609

Maingonnat C, Victor R, Bertrand P, Courel MN, Maunoury R and Delpech B (1999) Activation and inhibition of human cancer cell hyaluronidase by proteins Analytical Biochemistry 268 30-34

Mark BL, Wasney GA, Salo TJ, Khan AR, Cao Z, Robbins PW, James MN and Triggs-Raine BL (1998) Structural and functional characterization of Streptomyces plicatus $\beta-N$-acetylhexosaminidase by comparative molecular modeling and site-directed mutagenesis Journal of Biological Chemistry 273 19618-19624

Meyers SA, Yudin AI, Cherr GN, Vandevoort CA, Myles DG, Primakoff P and Overstreet JW (1997) Hyaluronidase activity of macaque sperm assessed by an in vitro cumulus penetration assay Molecular Reproduction and Development 46 392-400

Myles DG and Primakoff P (1997) Why did the sperm cross the cumulus? To get to the oocyte. Functions of the sperm surface proteins $\mathrm{PH}-20$ and fertilin in arriving at, and fusing with, the egg Biology of Reproduction 56 320-327

Overstreet JW, Lin Y, Yudin AI, Meyers SA, Primakoff P, Myles DG, Katz DF and Vandevoort CA (1995) Location of the $\mathrm{PH}-20$ protein on acrosomeintact and acrosome-reacted spermatozoa of cynomolgus macaques Biology of Reproduction 52 105-114

Primakoff P, Cowan A, Hyatt H, Tredick-Kline J and Myles DG (1988) Purification of the guinea pig sperm $\mathrm{PH}-20$ antigen and detection of a site-specific endoproteolytic activity in sperm preparations that cleaves
$\mathrm{PH}-20$ into two disulfide-linked fragments Biology of Reproduction 38 921-934

Sabeur K, Cherr GN, Yudin AI, Primakoff P, Li MW and Overstreet JW (1997) The PH-20 protein in human spermatozoa Journal of Andrology 18 151-158

Sarason RL, Vandevoort CA, Mader DR and Overstreet JW (1991) The use of nonmetal electrodes in electroejaculation of restrained but unanesthetized macaques Journal of Medical Primatology 20 122-125

Strobl B, Wechselberger C, Beier DR and Lepperdinger G (1998) Structural organization and chromosomal localization of Hyal2, a gene encoding a lysosomal hyaluronidase Genomics 53 214-219

Tollner TL, Yudin AI, Cherr GN and Overstreet JW (2000) Soybean trypsin inhibitor as a probe for the acrosome reaction in motile cynomolgus macaque sperm Zygote 8 127-137

Toole BP (1997) Hyaluronan in morphogenesis Journal of Internal Medicine $24235-40$

Triggs-Raine B, Salo TJ, Zhang H, Wicklow BA and Natowicz MR (1999) Mutations in HYAL1, a member of a tandemly distributed multigene family encoding disparate hyaluronidase activities, cause a newly described lysosomal disorder, mucopolysaccharidosis IX Proceedings National Academy of Sciences USA 96 6296-6300

Tung JS, Mark GE and Hollis GF (1994) A microplate assay for hyaluronidase and hyaluronidase inhibitors Analytical Biochemistry 223 149-152

Van Roey P, Rao V, Plummer TH, Jr and Tarentino AL (1994) Crystal structure of endo- $\beta$ - $N$-acetylglucosaminidase $F 1$, an $\alpha / \beta$-barrel enzyme adapted for a complex substrate Biochemistry 33 13 989-13 996

Victor R, Chauzy C, Girard N, Gioanni J, d'Anjou J, Stora DN and Delpech B (1999) Human breast-cancer metastasis formation in a nude-mouse model: studies of hyaluronidase, hyaluronan and hyaluronan-binding sites in metastatic cells International Journal of Cancer 82 77-83

West DC and Kumar S (1989) The effect of hyaluronate and its oligosaccharides on endothelial cell proliferation and monolayer integrity Experimental Cell Research 183 179-196

Withers SG and Aebersold R (1995) Approaches to labeling and identification of active site residues in glycosidases Protein Science $\mathbf{4}$ 361-372

Yang B, Zhang L and Turley EA (1993) Identification of two hyaluronanbinding domains in the hyaluronan receptor RHAMM Journal of Biological Chemistry 268 8617-8623

Yudin Al, Cherr GN, Vandevoort CA and Overstreet JW (1998) Rearrangement of the $\mathrm{PH}-20$ protein on the surface of macaque spermatozoa following exposure to anti-PH-20 antibodies or binding to zona pellucida Molecular Reproduction and Development 50 207-220

Yudin Al, Vandevoort CA, Li MW and Overstreet JW (1999) PH-20 but not acrosin is involved in sperm penetration of the macaque zona pellucida Molecular Reproduction and Development 53 350-362

Zverlov V, Mahr S, Riedel K and Bronnenmeier K (1998) Properties and gene structure of a bifunctional cellulolytic enzyme (CelA) from the extreme thermophile 'Anaerocellum thermophilum' with separate glycosyl hydrolase family 9 and 48 catalytic domains Microbiology 144 457-465

Received 21 September 2000.

First decision 10 November 2000.

Accepted 5 January 2001. 